\title{
VILÉM FLUSSER: FILOSOFIA DO EXÍLIO E LEITURA DE UM PAÍS CHAMADO BRASIL ${ }^{1}$
}

\section{Márcio Seligmann-Silva}

\section{As Pontes}

Vilém Flusser é autor de um pequeno e contundente texto escrito em inglês batizado com o título “The bridge”. Esta engenhosa peça autobiográfica abre o volume Jude Sein organizado por Stefan Bollmann e Edith Flusser. O texto se inicia com uma descrição da casa da infância do autor em Praga. Nos fundos desta casa encontrava-se a fábrica do avô materno, Julius Basch, elegantemente denominada de "Fabrique des colorants inoffensifs". Ligando a cozinha do avô ao prédio da fábrica havia uma ponte que dava diretamente na cobertura da fábrica, onde havia um jardim. Desta ponte Vilém e sua irmã Ludvika costumavam observar os trabalhadores no pátio da fábrica. Disputando os olhos curiosos deles andava também neste mesmo pátio o enorme cão São Bernardo "Barry”. Esporadicamente as crianças se divertiam galopando sobre ele. Mas, em um belo dia de 1926, narra este texto, os irmãos Flusser viram Barry, que brincava com um dos funcionários, repentinamente virar-se. Ele atacou este funcionário que caiu no chão e um jorro de sangue ficou a escorrer de sua perna, que Barry não queria mais largar. Flusser narra esta história como uma espécie de Denkbild benjaminiano, ou seja, como uma pequena imagem que condensa um aspecto importante de sua experiência de vida. Este incidente ensinou a ele que pode haver algo como "uma metamorfose repentina do bem em uma brutal agressão" (Flusser 1995: 10). Este episódio de 1926 ele conecta - em uma espécie de ponte metafórica - com a virada ocorrida na sua vida e na dos milhares de judeus de Praga em 1939 graças à "repentina mudança de atmosfera com a ocupação nazista. Aos meus olhos", escreveu Flusser, "Praga é como um cão São Bernardo Barry"

\footnotetext{
${ }^{1}$ Este texto é uma versão da palestra apresentada no Simpósio Internacional "A terceira margem: Vilém Flusser und Brasilien. Kontexte - Migration - Übersetzungen/ Vilém Flusser e o Brasil. Migração Contextos - Traduções", realizado entre os dias 12 e 14 de outubro de 2006. Este evento foi organizado pelo Fachbereich Angewandte Sprach- und Kulturwissenschaft, Johannes Gutenberg Universität Mainz e teve lugar na cidade de Germersheim, Alemanha.
} 
(Flusser 1995: 11). A virada que ele testemunhara com seu cão já o preparara para esta outra terrível virada.

Mas se Flusser afirma que desde então, ou seja, dos seus 6 anos de idade, ele não gostou mais de pontes, por outro lado ele não deixou de admirar uma ponte em particular, também localizada em Praga, a saber, a famosa Ponte de Carlos. Em seu ensaio sobre "Praga, a cidade de Kafka" ele destacou várias analogias ou afinidades eletivas entre a geografia física e psicológica de Praga e o universo das obras kafkianas. Uma peça fundamental nesta geografia é justamente esta ponte, que é descrita como "um elo impossível, mas realizado, entre Castelo e igreja, entre monte e vale, entre o rei e o burguês, entre a soberba e a humildade, entre a rua dos alquimistas e a universidade, entre o céu e a terra, entre o 'Castelo' e a aldeia de Kafka” (Flusser 2002: 64). Praga é marcada por esta imponente e delicada ponte, justamente porque é um espaço de tensões e campos de força. Esta cidade viveria de sua própria dissolução. Flusser a descreve como uma cidade "situada nas fronteiras" (Flusser 2002: 65). Kafka seria um "pontífice", ou seja, segundo Flusser, um “construtor de pontes impossíveis". Nele percebemos a "posição flutuante e duvidosa do praguense com relação a sua "nacionalidade", que se explicita sobretudo nos momentos em que esta cidade foi ocupada. O triângulo cultural entre o alemão, o tcheco e o judeu ditava a característica desta cidade como campo de passagem entre fronteiras. Kafka também transitava, como Praga, entre o Gótico e o Barroco, entre o ocidente e o oriente europeus, e sua língua era simplesmente "o próprio alemão praguense". (Flusser 2002: 67) Mas Flusser no seu apanhado das pontes que marcam a obra de Kafka e no seu paralelo com a Praga da ponte de Carlos, também desemboca, inexoravelmente, na virada, na metamorfose repentina, ou seja, na "mordida de Barry". Ele recorda que Praga, que era a unidade destes mundos e sobretudo destas três culturas — a alemã, a tcheca e a judaica —, tornou-se inteiramente outra com a eliminação dos seus judeus (Flusser 2002: 65). O "pontífice" Kafka teria conseguido ainda congelar e passar adiante, nas imagens de sua obra, uma cultura que foi extinta. As metamorfoses que ele narrou, aprendemos poucos anos após a sua morte, eram antevisões de metamorfoses muito mais terroríficas do que ele pudera imaginar. 
Neste texto eu gostaria de me deter em alguns aspectos da obra de Flusser que se relacionam com esta virada na sua história, na história de Praga e na da Europa. Minha proposta é tentar indicar na obra deste pensador as marcas desta metamorfose, mas também deste verdadeiro culto da "ponte". O "pontificado" de Flusser se estende sobre a linguagem. Mas como, para ele, língua é realidade, este pontificado é uma tentativa de (re)construir pontes após o abalo sísmico provocado pelo nazismo. Suas pontes são tanto internas, sentimentais, tentativas de diálogo com a sua cultura perdida, como também uma resposta ao enlouquecimento da língua, que se tornara monolíngüe e deste modo bloqueou abruptamente e com violência a circulação entre as línguas e visões de mundo que caracterizavam o seu universo. Flusser, o grande comunicólogo, é antes de mais nada um tradutor, Über-Setzer, e teórico da tradução, um analista e projetista de "pontes". Ele cultiva a plurilíngua como resposta ao choque da monolíngua exterminacionista, mas também, antes de tudo, como um modo de manter laços, pontes, com a sua Praga, que permaneceu uma matriz de seu pensamento. Ele foi um dos pensadores que no século XX melhor souberam extrair forças da catástrofe. Sua reflexão sobre a cultura, que mostrarei aqui, ainda que brevemente, é na verdade uma tentativa de "virada do punhal" que o expulsou da Europa e aniquilou a sua família. Flusser nesta virada desconstrói incessantemente o "ovo da serpente" que ele localiza em uma concepção ontologizante de identidade. Sua posição de exilado, sua experiência de ter que viver radicalmente um corte com sua "origem", não pode ser esquecida quando lemos sua obra. Minha tese, resumidamente, é que esta experiência construiu dentro de Flusser um espaço privilegiado, lançou-o como que sobre uma ponte que atravessa nossa cultura, de onde Flusser desfrutou de uma visão sui generis, desestabilizadora, da sociedade. Esquematicamente apontarei em seguida dois importantes aspectos de sua obra relacionados com a sua situação de exilado: a) primeiro veremos a questão da sua paradoxal "exemplaridade" no contexto do século XX. Trata-se de tentar pensar sua posição de exilado e de judeu como representante de uma era marcada pelas catástrofes. Aqui veremos como certos aspectos da sua teoria da cultura se relacionam com este projeto que denomino, inspirado pelo próprio Flusser, como sendo um pontificado, no sentido de um projeto de construção de pontes. b) Em um segundo passo veremos um aspecto específico da obra de Flusser, a saber, sua leitura 
do Brasil, como parte deste seu projeto. Aqui a sua reflexão sobre a migração e o exílio recebe uma nova luz a partir desta experiência de 32 anos de engajamento em uma outra cultura e língua.

\section{Ser Judeu: Bodenlos e Heimatlos}

Ruth Klüger em seu relato autobiográfico weiter leben, que narra como ela sobreviveu à Shoah, utiliza uma metáfora que não nos surpreende a esta altura: sua narrativa funcionaria como uma tentativa de ligar os pilares de uma ponte ruída, ou seja, os pontos de sua própria vida que ficaram ilhados pela destruição da guerra. Flusser, portanto, fez parte de uma equipe de construtores de pontes neste século de extermínios e guerras. Como outros pensadores exilados e sobreviventes da perseguição, ele desenvolveu seus teoremas em diálogo com a sua época. Nesta parte de minha reflexão gostaria de apresentar alguns aspectos da sua teoria da judeidade e dos conceitos correlatos de Heimatlosigkeit ("apatricidade") e de Bodenlosigkeit (falta de fundamento). A idéia é localizar um pouco esses conceitos dentro do panorama intelectual da segunda metade do século XX.

A judeidade de Flusser, tal como podemos ler em suas idéias acerca desta questão na sua obra, foi antes de mais nada pensada a partir do fenômeno cultural único que era a cidade de Praga. Como filho de um professor universitário "completamente agnóstico, ainda que interessado ativamente no judaísmo" (Flusser 1995: 14), Flusser se apresenta como um judeu assimilado, não-ortodoxo e nãosionista. Em Praga sentia a questão da identificação nacional como algo "arcaico e secundário" (Flusser 1992: 16). É claro que ele escreve isto de sua perspectiva de judeu (impermeável aos nacionalismos germânico ou tcheco) e anti-sionista. Para ele, em Praga era-se "internacionalista de nascimento (e não ideologicamente), pois as pessoas sentiam na própria existência o ridículo de se fazer diferenças claras entre os povos." (Flusser 1992: 16) O sionismo ele descartava, pois via nele um nacionalismo, uma reação ao anti-semitismo e ao nazismo e porque atribuía ao judaísmo um papel “diametralmente oposto ao que o judaísmo desempenhava em Praga, a saber, ser ponte entre os povos" (Flusser 1992: 17; eu grifo).

Ser judeu, para Flusser, portanto, não significava de modo algum se encastelar em uma cultura fechada. Muito pelo contrário, a judeidade para ele era 
também um avatar de sua doutrina das "pontes". Daí ele não se sentir "completamente judeu", ou seja, totalmente e exclusivamente judeu. Ser judeu para ele significava saber circular entre as culturas. Ele se dizia "ser por demais 'grego', 'romano', 'germano' e 'cristão' para ser totalmente judeu” (Flusser 1995: 60). Os "limites da judeidade" fazem parte do "ser judeu". Este deve encarar a sua tarefa de sintetizar as culturas. Mas cada um realiza sua síntese ao seu modo. Flusser toma como elogio as palavras derrisórias dirigidas contra os judeus: "Heimatlos" e "Cosmopolita". Indica-se assim que eles não teriam raízes. Na verdade ser fiel às raízes, para ele, significa superar (überholen) as suas idiossincrasias. (Flusser 1995: 61) Isto significa dizer, o que Flusser de fato faz em certos momentos, que o ser humano não é uma planta. Nosso estar no mundo é marcado pelo fluxo — pelo Fliessen! - e não por sermos seres estáticos plantados em culturas estáticas. Daí a admiração de Flusser pela cultura judaica em ambientes multilingües e multiculturais, como a Praga de antes da guerra e a Alexandria da era helênica. (Flusser 1995: 67) Daí também sua concepção do judaísmo como uma ponte que não apenas liga culturas, mas também as conecta com a tradição. A grande contribuição do pensamento judaico seria sua dívida de memória, ou seja, o mandamento da Zehker, que escandaliza o modo de pensar anti-histórico grego. (Flusser 1995: 70) Lembrando de várias figuras judaicas de destaque ele propõe que cabe ao judeu produzir modelos. (Flusser 1995:72) Estes modelos seriam figuras paradoxais, nascidas desta situação ao mesmo tempo atopica - Bodenlos - que o judeu encarna, e de seu engajamento com a construção de pontes. Acredito que o próprio Flusser representaria este papel paradoxal: na sua vida única e inimitável ele representa um tipo de pensador e uma postura existencial que é modelar em vários sentidos, assim como ele via no judeu e seu pontificado um modelo aberto a todos.

No seu pequeno texto de 1990 "Pontificar" ele explora a idéia da tradução como construção de pontes. Aí ele afirma que os pontífices (construtores de pontes) seriam essenciais, hoje mais do que nunca. Eles deveriam permitir o trânsito não apenas entre as diversas línguas (trânsito impossível, mas necessário), como também entre o discurso verbal e o imagético, entre o conceito e o algoritmo, entre a música e as demais linguagens. (Flusser 1998b: 199) Traduzir implicaria um "salto entre universos". (1998b: 198) Se traduzir equivale a "levar de um lado para o outro" esta 
atividade é metáfora (no sentido etimológico desta palavra). Mas se, por outro lado, Flusser precisa que "tradução e metáfora não são a mesma coisa", ele não deixa de enfatizar - ponto essencial para ele — que "pensar e traduzir são sinônimos, e não apenas para poliglotas.” (1998: 199s.) Ser “judeu” para ele significava encarnar esta tarefa pontífica de "oscilar" (Schweben, como diriam Friedrich Schlegel e Novalis) e transitar entre universos. Sua Bodenlosigkeit (falta de chão, de terra e de fundamento) abria-lhe a perspectiva de ser um nômade entre as diversas línguas e linguagens. Ao mesmo tempo de sua "ponte" ele via que as disciplinas, nações e linguagens específicas são nômades e vivem de uma constante crise e de um fluxo que põe em questão as suas identidades, como o próprio indivíduo deve ser visto como um tal fluir. Ele tinha como projeto que toda a humanidade pudesse se tornar Bodenlos e praticar o pontificado. $^{2}$

Flusser se coloca a questão “Como viver após Auschwitz?” (Flusser 1995: 64) e uma de suas respostas é uma proposta de abertura do judaísmo. Ao invés do sionismo, que representaria um movimento de fechamento, sístole (que ele até entende e chega a chamar de digno), ele propõe uma diástole, ou seja, uma abertura ao "outro". (Flusser 1995: 66) Este movimento foi o que ele mesmo seguiu em sua vida e em seu pensamento. Ele se manteve na diáspora assim como continuou fiel, ao seu modo, ao seu judaísmo. Ele nunca tentou reconstruir as ruínas de seu passado em Praga. Sintomaticamente a volta àquela cidade significou o momento trágico do encontro de sua morte. Como se seu destino existencial e filosófico fosse mostrar que o engajamento no e pelo outro não se dá via uma artificial recuperação do passado. A rememoração, Zehker, deve ser feita com os olhos voltados para o presente. O passado não é Deckerinnerung (memória encobridora), mas meio de se pensar o presente. Com esta mirada de Flusser podemos fazer uma crítica de nossos hábitos de reconstruir ruínas e cidades destruídas pela guerra como se nada tivesse acontecido. O seu modelo do engajamento no presente a partir dos cortes (com o passado e com as ideologias nacionalistas) ainda tem muito a desconstruir.

\footnotetext{
2 Em um artigo de 1970 intitulado "Sobre a Ponte de Avignon" Flusser (1970) utiliza a imagem da ponte em ruínas da ex cidade papal para representar a Europa em meio aos movimentos de contestação estudantil. Ele faz neste texto um rasgado elogio da vida européia (e sobretudo da Province, para onde se mudaria dois anos depois). O interessante neste texto é que nele percebemos novamente como Flusser pensava a ponte como um topos com teor epistemológico. Vemos como ele "sobre a ponte de Avignon" observa seu mundo como uma espécie de "observador de segunda ordem".
} 
Sua experiência de vida deixou-o particularmente aberto para uma obra como Le Bouc Émissaire de René Girard, comentada por ele em um texto de 1982 (mesma data da publicação do livro). A tese central deste livro, segundo a qual as sociedades em momentos de caos e de dissolução lançam mão de bodes expiatórios para gerar novamente uma unidade, ele vivera na própria carne. Ele sabia como funciona este mecanismo psicológico que faz com que "[s]empre nos identificamos como os estrangeiros dos estrangeiros." (Ou: como os "estranhos aos estrangeiros", Wir identifizieren uns immer als die Fremden des Fremden; 1995: 105.) Flusser apresenta a partir de Girard uma teoria da identidade como um gesto de exclusão assassino. “"Wer bin ich?’ ist eine kriminale Frage" (“Quem sou eu? É uma frase criminosa”), ele anotou então. (Flusser 1995: 101) Todo ato de auto-afirmação depende deste "crime". O bode expiatório, como a figura biopolítica do homo sacer estudada por Agamben, seria caracterizado pela ambigüidade entre o sacro e o sagrado. Esta ambigüidade na verdade seria a marca de toda experiência religiosa. Daí a centralidade do sacrifício nos ritos, destacada por Girard e, antes dele, por Marcel Mauss. Flusser apresenta a própria estrutura do mito como calcada no sacrifício, no assassinato. Os mitos seriam figuras do recalcamento da culpa. Não deixa de ser admirável que Flusser não cite neste contexto a teoria freudiana de "Totem e Tabu" da tragédia grega como reencenação (culposa) do assassinato do pai da "horda primeva". Flusser afirma que "quanto pior é a nossa consciência tanto mais cruel tornam-se nossos crimes". (Flusser 1995: 105) Esta tese revela nossa sociedade atual, como suas desigualdades gritantes, como um campo fértil para massacres.

A sua situação de exilado e esta reflexão sobre o dispositivo de identidade como um dispositivo xenófobo e "outricida" lançam também luz sobre a sua potente teoria da Heimatlosigkeit, tal como lemos no ensaio "Wohnung Beziehen in der Heimatlosigkeit. (Heimat und Geheimnis - Wohnung und Gewohnheit)". (Flusser 1992: 247-264) Aqui trata-se também de modo explícito de uma reflexão retirada da sua própria experiência de vida. Daí este trabalho ter sido acolhido no volume autobiográfico Bodenlos. Este texto é um fruto da reflexão do seu autor sobre a sua origem judaica em Praga e sobre seu exílio em São Paulo. Ele se inicia com uma descrição do autor que conclui com estas palavras: "Em suma, sou heimatlos, porque muitíssimas pátrias [Heimaten] se armazenam em mim. Isto se manifesta diariamente 
no meu trabalho. Eu sou apatrizado [beheimatet] em pelo menos quatro línguas e me vejo exortado e obrigado a traduzir e retrotraduzir tudo a-escrever [Zu-Schreibend]." (Flusser 1992: 247) Deste fato ele também deduz seu interesse pela comunicação, pelos buracos entre os lugares e "pelas pontes que cobrem estes buracos". (Flusser 1992: 247; eu grifo) “Talvez este interesse pode ser deduzido do meu próprio pairar [Schweben] sobre estes lugares", ele arrematou. O seu texto de um modo geral se apresenta como uma reflexão teórica a partir deste "transcender das pátrias". Ele parte, nesta teoria, da diferença entre o gesto de habitar e o de ter uma pátria. O ser humano desde os tempos mais remotos sempre habitou algum lugar, mas apenas recentemente se tornou agregado a uma pátria, Heimat. Esta é a proto-verdade que o exilado Flusser descobre a partir da sua "ponte". "Nós, os incontáveis milhões de migrantes (sejamos trabalhadores estrangeiros, exilados, fugitivos ou intelectuais andando de seminário em seminário), nos reconhecemos não como excluídos [Aussenseiters], mas antes como vanguardas [Vorposten] do futuro." (Flusser 1992: 249) Ao invés de pessoas dignas de pena, estes deslocados seriam "modelos" (Id.), pois a migração, além de ser um sofrimento, é uma ação criadora.

Parafraseando uma das teses sobre a filosofia da história de Benjamin, esta postura pode ser vista como o "Salto tigrino" de Flusser sobre o céu das catástrofes do século XX: ele transforma a sua Leidengeschichte em um modelo positivo. Mas não se trata de um modelo de sofrimento, de um martirológio. Muito pelo contrário, Flusser escreve relativamente pouco sobre a destruição dos judeus da Europa. Antes, ele executa uma reviravolta na sua posição, passando de vítima a modelo de um novo homem. Neste ponto ele pode ser aproximado de um escritor como Witold Gombrowicz, que aportou em Buenos Aires no início da guerra e que aí ficou exilado por quase 25 anos. Gombrowicz reverteu este exílio em uma espécie de deserção voluntária. Seu exílio transformou-se em um antídoto contra o patriotismo e o ufanismo. Gombrowicz viveu de sua Felix culpa de cidadão sem pátria que abraçou (não sem ambigüidades) a Filiatria. Abandonar o "velho", a pátria, e entregar-se ao novo, à ausência de pátria, foi o caminho para seu renascimento. Esta foi a sua conversão, para lembrarmos de Santo Agostinho. Trata-se, no seu caso, de uma paixão pelo deambular sem rumo e pelo que é considerado menor, desprezível. Esta paixão também tem afinidades com o culto da superfície que lemos em Flusser. 
Desviar da Verdade era a sua meta. Suas obras literárias, assim como os escritos teóricos de Flusser, também são altamente marcadas por teor autobiográfico. (Cf. Gasparini 2006) Estes autores partem do lugar do exílio para escrever. Eles lançam um "outro olhar" que rompe com o automatismo de nosso pensamento. Daí as suas obras envolverem visceralmente as suas vidas. De certo modo uma das primeiras verdades que eles desmontam é a falácia da autonomia da obra diante da vida.

Mas voltando à filosofia da Heimatlosigkeit que Flusser derivou de seu exílio, ele viu na sua saída de Praga um "desabamento do Universo", mas também, dialeticamente, uma "vertigem da libertação e do ser-livre". (Flusser 1992: 249) Como Walter Benjamin em seu "Erfahrung und Armut" de 1933, que realizou a reviravolta da posição melancólica para uma comemoração da "nova barbárie positiva" e da liberdade que ela significa com relação ao peso do passado, Flusser viu nesta ruptura dos seus laços com a sua Heimat-Praga uma libertação do sedentarismo e um mergulhar no nomadismo. A quebra da pátria também serve de laboratório para a decomposição e análise de seus elementos originários e estruturais. Entre eles Flusser detecta uma "memória não-articulada", "fetal", que amalgama os indivíduos à Heimat, e constitui uma das mais potentes matrizes de preconceitos. A Heimat é o dispositivo por excelência da identidade moderna. Sob suas assas é chocado o ovo do preconceito contra o outro. Se toda identidade é assassina, como Flusser destacou a partir de Girard, então mais do que nunca o pensamento a partir da Heimat o é. Assim, Flusser mostra como o Heimatlos incomoda aquele que habita na clausura protetora da Heimat: o Heimatlos revela como tudo aquilo que este acreditava formar as verdades mais "originárias, únicas e inimitáveis", ou seja, tudo o que a sua Heimat significa, pode ser mimetizado. O estrangeiro, para falarmos de um modo que recorda a Genealogia da Moral de Nietzsche, revela que a Heimat é um constructo de hábitos decantados, cristalizados, cuja origem foi esquecida. Ele profana e dessacraliza a Heimat. Ele mostra como as regras da Heimat são banais. (Flusser 1992: 253) Como conseqüência o estrangeiro é ainda mais odiado e estigmatizado. Ele é apontado como o "outro" do próprio, o "feio e digno de ser odiado". (Flusser 1992: 254) A Heimat é a matriz da ontotipologia, da criação dos tipos, das "formas ideais", que se querem puras e se relacionam com a teoria das formas platônicas na medida em que este pensamento da propriedade da Heimat é 
inimigo das noções de cópia e de simulação, tanto quanto Platão o foi e por isso expulsou o poeta de sua República ideal.

Em termos lingüísticos Flusser já expressara esta reflexão sobre o discurso da identidade em seu primeiro longo ensaio, o Língua e Realidade. Em um capítulo dedicado à tradução ele mostrou tanto que a noção tradicional de tradução é platônica — no sentido de acreditar na existência de uma "coisa em si" separável e autônoma da linguagem - , como também a impossibilidade da tradução, na media em que ele via justamente a linguagem como inexoravelmente condicionando e criando o mundo. (Cf. Flusser 2004b: 16) Língua é realidade: No início foi o verbo. Mas a língua não é toda a realidade e sim apenas um aspecto dela. Como na doutrina das formas internas de cada língua, que W. v. Humboldt desenvolvera, Flusser também vê cada língua como uma parte da realidade. Neste sentido a tradução seria um ato que transgride os limites do mundo. (Cf. Flusser 2004b: 22) Na metáfora benjaminiana da tradução, esta, estabelecendo pontes entre as diversas Arten des Meinens ("modos de pensar") de cada língua, permitiria se construir $a$ língua a partir da qual a realidade poderia ser vista de modo integral. ${ }^{3}$ Mas existe uma resistência à tradução no coração da identidade, da Heimat. Neste sentido é importante destacar aqui como Flusser sublinha o comportamento nacionalista das pessoas com relação às suas línguas. A língua materna é confundida normalmente com a realidade, como se houvesse apenas esta única visada sobre o mundo. “Aquele que não fala a 'língua da gente', ou fala mais de uma língua, é suspeito”, (Flusser 2004a: 59), escreveu então Flusser, com amplo conhecimento de causa. A tradução é vista e valorizada por ele como uma possibilidade de afastamento da língua e da Heimat a ela correlata. ${ }^{4}$

\footnotetext{
${ }^{3}$ Apesar de muitas semelhanças que podem ser traçadas entre a teoria da tradução de Benjamin e a de Flusser - que se devem sobretudo a esta tradição humboldteana de pensar a língua como a realidade existem diferenças fundamentais entre estes dois pensadores neste ponto. Benjamin é um seguidor da tradição mística que afirma a existência de uma linguagem originária, inscrita no mundo. Sua teoria da queda da linguagem, calcada no Gênese, não é apenas uma bela metáfora. Já Flusser se baseia em Wittgenstein pra construir uma teoria da tradução muito mais pragmática que mística. Ele descarta, por exemplo, a necessidade de se pensar em uma Ursprache para se tratar a questão da tradução. (Flusser 2004b: 29)

${ }^{4}$ A valorização flusseriana da circulação entre as línguas e da tradução como forma de alargamento do horizonte do pensamento, coloca-o em um ponto divergente daqueles exilados que vêem na língua materna um local possível para se manter "dentro" da Heimat. Tanto Adorno como H. Arendt já foram criticados por Derrida por este apego nacionalista e metafísico à Muttersprache. Cf. Derrida 100ss. Hannah Arendt, em uma conhecida entrevista a Günter Gaus nos anos 1960, afirmou que apenas a língua alemã havia lhe restado da Alemanha pré-hitlerista. Contra esta posição de centralidade da língua
} 
Sair da Heimat significa galgar um campo livre para o julgamento — ou ao menos mais livre, do que aquele que vive sob a sua campânula asfixiante. Flusser tende a apresentar suas trocas de Heimat como se fossem trocas de roupas: assim ele passou de Praga, para Londres, para São Paulo, para Robion, mudando sucessivamente de "Heimat". A cada corte de sua relação com uma Heimat ele foi se tornando mais independente desta ancoragem identitária. Evidentemente o primeiro corte foi o mais radical e o mais traumático. Foi o único que pode ser chamado mais propriamente de exílio. Os demais foram migrações. A saída de Praga estava ligada à sua sobrevivência. A quebra daquela Heimat foi condicionada pela morte de todos os que o ligavam a ela. ${ }^{5}$ Mas justamente esta radicalidade não deixava escolhas. Daí Flusser escrever que "o partir do nó górdio de Praga foi mais fácil." (Flusser 1992: 252) Para ele, a liberdade do migrante permite que ele supere, aufhebt, as suas pátrias. Ele não apenas teria rompido com suas pátrias, mas antes as incorporado: ele se define como praguense, paulistano, robionense e judeu além de se localizar dentro do círculo cultural alemão. (Flusser 1992: 253)

Esta idéia de um acúmulo de "pátrias" é interessante porque permite ao mesmo tempo se estabelecer uma aproximação e um distanciamento da teoria que Derrida realizou sobre a sua "prótese de origem" em seu ensaio Le monolinguisme de l'autre. Neste livro ele fala desta sua situação ao mesmo tempo excepcional e exemplar de errância identitária. Exemplar porque ela "representa ou reflete uma espécie de 'alienação' originária que institui toda a língua como língua do outro: a impossível propriedade de uma língua.” (Derrida 2001: 96) Com este raciocínio Derrida apresentava um forte argumento contra os nacionalismos e fundamentalismos (que têm levado aos "etnicídios"). Enquanto um judeu nascido na Argélia - falante de francês e "exilado" do árabe, do berbere e do hebraico — bem como na qualidade de professor e palestrante que transitou constantemente entre dois

materna cf. também Jorge Semprun (1995: 75), onde ele critica a afirmação de Thomas Mann que dizia que sua pátria era a língua alemã.

${ }^{5}$ É importante este exílio estar localizado na origem da desconstrução flusseriana da Heimat como grande local de ancoragem da identidade. Isto revela o grau de sofrimento e a violência que originou no século XX a abertura para uma nova postura diante da identidade. Isto explica porque é mais acertado chamar a sua reflexão sobre a Heimat e a identidade como uma filosofia do exílio e não como uma simples filosofia (ou como um elogio) da emigração. Esta filosofia, lamentavelmente, ainda está longe de ser a predominante hoje. A cada dia acompanhamos os efeitos da concepção tradicional de Heimat, que agora sofreu um recrudescimento ao se misturar a elementos biológicos (nunca se falou tanto de raça desde o nazismo como hoje em dia) e religiosos. 
universos culturais e lingüísticos, a França e os Estados Unidos, ele também pensava entre as línguas e apresentava uma consciência fora do comum da tarefa tradutória. Essa situação de morador de várias "casas" decerto também aguçou a sensibilidade de Derrida não apenas para as diversidades culturais e da linguagem, mas sobretudo para os limites da linguagem e para a situação de "ser estrangeiro" (ainda que com privilégios óbvios) e ter que assumir uma nova mise en scène condizente com sua nova moradia. Ou seja, como Flusser, seu atopismo o tornou particularmente indicado para descrever nossos cenários de guerras etnocêntricas e a ação de nossas monolínguas cegas e surdas ao "outro". Também muito atual é uma de suas conclusões derivadas dessa sua experiência entre as línguas e culturas: como ele escreveu também em O monolinguismo do outro (2001: 37), “o senhor não é nada. Ele não tem nada de próprio". Flusser também denunciou o "imperialismo de todos universos" (1998b: 199), no sentido de que toda língua quer dominar a outra. Assim como ele notou que toda identidade é assassina, Derrida escreve que é essa falta originária da cultura - seja ela metropolitana ou colonizada, central ou periférica que leva a língua ciumenta ao gesto colonizador, violento. Se Flusser deferencia o morar do ter uma pátria, Heimat, para Derrida deveríamos manter uma certa desconfiança diante da própria noção de "casa": "Todas estas palavras: verdade, apropriação, habitação, 'casa (própria)' [chez-soi], ipseidadade, lugar do sujeito, lei etc., permanecem problemáticas aos meus olhos”, ele escreveu. (Derrida 2001: 91).

\section{O Brasil visto por um imigrante: reprodução e desconstrução de um mito}

Mas voltemo-nos agora, em um último passo, para a leitura flusseriana do Brasil e para o seu papel na construção da sua filosofia do exílio. Flusser chega ao Brasil em 1940. Nesta época estava em vigor um decreto secreto, de 7 de junho de 1937, baixado, portanto, cinco meses antes do início do Estado Novo, que proibia a concessão de vistos às pessoas de "origem semita". (Lesser 2005: 318) Esta regra, que tinha clara inspiração no anti-semitismo onipresente no governo de Getúlio Vargas, não impediu, no entanto, que em 1939 entrassem mais de 4 mil judeus no Brasil de forma legal. Esta foi a maior taxa anual de imigração judaica dos 20 anos anteriores. (Lesser 2005: 318 e 321) Isto se explica pelo auxílio de muitas famílias já 
instaladas no Brasil, que se empenharam para conseguir trazer outros familiares que tentavam fugir da fúria nazista. O que historiadores como Roney Cytrynowicz já mostraram é que, apesar do anti-semitismo oficial da era Vargas, de um modo geral a maior parte da população brasileira não compartilhou deste anti-semitismo. Uma historiografia voltada para a vida cotidiana da pequena mas muito ativa comunidade judaica instalada no Brasil então, mostra que não ocorreram na época casos de violência física motivados pelo anti-semitismo. As instituições judaicas tinham uma vida múltipla, assim como, aliás, aquelas ligadas aos grupos de imigrantes dos países do Eixo, que passaram a ser vigiados mais de perto a partir de janeiro de 1942 (com o rompimento das relações com os países do Eixo) e sobretudo a partir de julho do mesmo ano, quando o Brasil declarou guerra ao Eixo.

Entre 1881 e 1942 entraram cerca de 4 milhões de imigrantes no Brasil, dentre o quais cerca de 65 mil judeus. Nas duas primeiras décadas do século XX estes judeus vieram sobretudo dentro de iniciativas organizadas por grandes organizações judaicas. (Cytrynowicz 2005: 289) Nos anos 1930-40 contavam-se ao menos 10 sinagogas em São Paulo, sendo que elas não se concentravam apenas no Bairro então judaico do Bom Retiro, mas também em outros núcleos de imigrantes, como a Vila Mariana, a Mooca, a Lapa, o Ipiranga e a Penha. As inúmeras organizações judaicas existentes nesta cidade então (voltadas para o assistencialismo, para a cultura, para o esporte e para a economia) ajudaram os imigrantes, sobretudo os recém-chegados fugitivos do nazismo, a se integrar no Brasil. Em 1936 foi fundada em São Paulo, como resultado da fuga dos judeus da Alemanha, a Congregação Israelita Paulista. Ela foi criada por imigrantes judeus-alemães e em 1938 já contava com 800 sócios. Mesmo o anti-semitismo ostensivo do partido fascista brasileiro, a Ação Integralista Brasileira, que atuou entre 1933 e 1938, não significou um cerceamento visível da liberdade dos judeus no país. É verdade que Gustavo Barroso, o mais anti-semita da agremiação política integralista, publicou livros anti-semitas como História secreta do Brasil e Brasil colônia de banqueiros, além de ter traduzido o famigerado e apócrifo panfleto Os Protocolos dos Sábios do Sião. Mas tampouco se tem registrado incidentes de ações violentas de integralistas contra judeus na época. (Cytrynowicz 2005: 294) É importante lembrar que o antisemitismo do Estado Novo, apesar de inimigo do integralismo, calcava-se também 
em teses raciais e visava um "branqueamento" do brasileiro. O "novo homem brasileiro" não deveria ter traços do semitismo. Mas isto era mais uma doutrina oficial do que uma idéia arraigada na população.

Flusser, por sua vez, vai se defrontar com este modelo de construção e um "homem novo" e se apropriar a seu modo dele. Ele também sonhará com o Brasil como berço de um "homem novo". Como ele escreveu: "Um novo homem está surgindo; em sua virtualidade ele pode representar, se alcançado, um modelo para uma humanidade em crise.” (1998a: 69) Novamente vemos Flusser em busca de novos modelos decantados da história. No Brasil se encontrariam "germes de um novo tipo humano." (Flusser 1998a: 1) Este "homem novo" seria o avesso daquele sonhado pela doutrina do Estado Novo. Ele seria justamente o Heimatlos. Na contramão das doutrinas raciais que dominavam a reflexão sobre a brasilidade nos anos 1940, Flusser vai desenvolver a partir da sua experiência do exílio e da migração, um ideal de uma pátria "pós-pátria", de um local pós-histórico, livre dos males que haviam levado a Europa ao buraco do nazismo e da auto-destruição. Em suma, Flusser pensou ter encontrado no Brasil um local para se concretizar uma espécie paradoxal de pós-identidade, que seria livre da fúria assassina da ontotipologia. Seu livro Fenomenologia do Brasileiro. Em Busca de um Novo Homem é o maior documento deste sonho e deste projeto de Flusser. Sua decepção com este engajamento no e pelo Brasil pode ser lido no ensaio acima comentado "Wohnung Beziehen in der Heimatlosigkeit. (Heimat und Geheimnis - Wohnung und Gewohnheit)". Este mergulho no Brasil, fruto de 32 anos de vivência neste país, mostra como o pensamento de Flusser foi se transformando junto com a sua experiência de mundo. Seu Hassliebe com relação a este país originou importantes reflexões, mas também aponta para alguns limites de sua teoria. Seu ideal de um "homem novo" é tão inocente quanto as imagens do bom selvagem dos séculos XVIII e XIX, ou seja, do rousseauismo e do romantismo europeu e brasileiro. Não caberia aqui apresentar os detalhes desta sua leitura inocente do "novo homem brasileiro". Teremos que nos contentar com algumas indicações.

Antes de mais nada é importante destacar com relação ao Fenomenologia que se trata de um livro brilhante e que merece ser lido pelos que se interessam tanto por uma fenomenologia deste país chamado Brasil, como pela filosofia do exílio de 
Flusser. O livro foi escrito a partir da posição de Flusser como imigrante. Ele valoriza este "pedestal", ou esta "ponte", para ficarmos na metáfora que vimos acima. Não por acaso Flusser trata logo no início do livro do que ele denomina de "Filosofia da Imigração e Imigração da Filosofia”. (Flusser 1998a: 38) Como ele escreveu, novamente revelando a sua exemplaridade peculiar, "uma descrição fenomenológica da situação imigratória pelo próprio imigrante deveria a rigor desvendar a estrutura de toda vida humana". (Flusser 1998a: 40) Lembremos aqui da noção de "“alienação' originária" da passagem de Derrida citada acima, que estaria na base de todas as línguas e, portanto, de toda cultura. O imigrante é a vanguarda da humanidade, seu modelo, ao menos se aceitarmos o projeto flusseriano de construir um mundo póshistórico e pós-Heimat.

Mas a leitura propriamente dita que Flusser apresenta do Brasil é um emaranhado de estereótipos locais ou por ele reciclados. Ele acredita e reproduz o mito da "cultura do coração que se manifesta na cortesia quase cavalheiresca" do brasileiro. (Flusser 1998a: 43) Lemos ainda que "está-se formando aqui uma solidariedade humana, solidariedade esta raras vezes conscientizada pelo brasileiro, mas óbvia para o imigrante, por contraste com a Europa.” (Flusser 1998a: 71) É verdade que não existem câmaras de gás para matar o "outro" ou os "subalternos" no Brasil, mas daí a se falar de uma solidariedade onipresente existe uma enorme distância. Flusser continua: "Muitas vezes foi dito que a cordialidade caracteriza o brasileiro. Aqui este traço se torna claro e merece a denominação, talvez melhor [!], de 'amabilidade'. Esta gente merece ser amada, já que não sabe ser odiosa." (Flusser 1998a: 71) Seria o caso de perguntar para qualquer habitante da grande cidade, ou mesmo para qualquer campesino brasileiro que é obrigado a trabalhar de sol a sol, qual o resultado desta "cultura do coração". Sem contar com os escravos e vítimas de torturas, fome etc. Uma outra interpretação deste mote seria que no Brasil, apesar de sua violência sempre reiterada nas relações entre as classes e inter-pessoais, pode-se constatar um "código do coração". Este seria ao menos um ponto de vista "crítico" para se pensar esta sociedade a partir desta noção. Sérgio B. de Holanda, que toma a expressão de Ribeiro Couto, recusa a noção (que pode ser ufanista) de uma "bondade" vinculada a este conceito, como parece ser o caso de seu uso da parte de Cassiano Ricardo (ainda que este fale também da cordialidade como uma "técnica da 
bondade", apud Holanda, 205). A cordialidade, eu tenderia a compreender hoje em dia, é o código de relacionamento que corresponderia à concomitância da exploração mais radical ao lado da aparente normalidade social. Portanto não se trata de nada elogiável, como pareceu a Flusser. Do ponto de vista de uma sociologia racista (típica do início do século XX), este traço seria fruto da "hibridez racial" do país: como se um "país mulato" (e rural) fosse cordial (não podendo ou conseguindo ser simplesmente urbano ou "civilizado" como as nações centrais).

O risco desta noção é o de regredir (talvez involuntariamente) à ontotipologia racista que ela quer exorcizar nesta versão sociológica, que pretende reduzir tudo ao “caráter nacional". Além disso, valeria a pena retraçar o percurso hegeliano (e também romântico) de Sérgio Buarque de Holanda que também está na raiz deste conceito, lembrando que Hegel - eurocentricamente, como não podia deixar de o ser - via as leis nas sociedades periféricas como aparições raquíticas, submetidas a outras instâncias sociais, sobretudo ao patriarcalismo. Holanda, mesmo se distanciando da tese que afirma a continuidade entre a família e o Estado (tese defendida por Hegel, por exemplo, nos seus Texte zur Philosophischen Propädeutik, de 1808), incorpora muitas idéias de Hegel, seja por via direta ${ }^{6}$, seja através de M. Weber e de C. Schmitt. Hegel na sua Fenomenologia do Espírito também narra o confronto "violento" entre a "lei do coração" e a "ordem do mundo". (Hegel 1993: III, 275s.) É evidente que existem diferenças entre a teoria da cordialidade de Holanda e a "epopéia do espírito" descrita por Hegel, mas vale a pena conferir as proximidades entre elas também. Além disso, não podemos esquecer que Hegel nas suas preleções sobre filosofia da história já defendera a tese de que no Brasil haveria uma maior facilidade para os negros se tornarem livres, já que os portugueses teriam sido mais "humanos" que os holandeses, espanhóis e ingleses. Flusser não reproduz diretamente este ideário de Hegel e de Sérgio Buarque, mas podemos escutar inúmeras reverberações destas idéias na sua Fenomenologia. Ele elabora uma ontologia da brasilidade e do brasileiro que é incompatível com a sua proposta de um pensamento pós-histórico. Ele essencializa o momentâneo. Frases do tipo "A meta destas considerações é aproximar-se da essência brasileira” (Flusser 1998a: 54); “O

\footnotetext{
${ }^{6}$ Cf. a passagem sobre a Antígona de Sófocles que abre o seu capítulo sobre o homem cordial, que, mesmo não citando Hegel, é um eco de sua análise desta tragédia na sua Estética; Hegel 993: XIV, 60.
} 
brasileiro é democrático existencialmente", (Flusser 1998a: 71) e "O brasileiro é homem do palpite genial, e não do planejamento" (Flusser 1998a: 53) seriam risíveis, se não tivessem por detrás um terrível pensamento ontotipológico. Ao invés de desmontar a fábrica de tipos - que me parece ser o resultado mais promissor da Filosofia do Exílio de Flusser - sua Filosofia da Imigração, ao reproduzir preconceitos, revela-se como um estrondoso fracasso. Além disso, Flusser revela neste ensaio uma visão da história linear e etapista. Ele chega mesmo, paradoxalmente, a apostar no progresso, ${ }^{7}$ o que também é incompatível com seu projeto de pós-história e de desmontagem crítica da Europa a partir de sua experiência. Neste sentido a filosofia da história de um Benjamin, com seu antievolicionismo, anti-historicismo e crítica do progresso, parece-me muito mais atual do que a esboçada por Flusser neste ensaio.

Por outro lado, não deixa de ser verdade que este ensaio, provocativo em alguns momentos, justamente devido à sua radicalidade, consegue quebrar a casca do ufanismo nacional brasileiro e tocar em pontos nevrálgicos, como o fato de não existir até hoje uma filosofia local digna do nome no Brasil ${ }^{8}$, voltada para refletir criticamente a realidade local e não apenas para realizar um trabalho de repetição filologicamente correta dos "grandes mestres do pensamento ocidental". Outro elemento digno de destaque deste ensaio de Flusser é seu modo sem-cerimônia de desmontar o culto da bela-natureza nacional. Com isto ele põe em movimento e fratura mitos que, de fato, apenas a visão do imigrado permite realizar.

Mas a inocência do próprio Flusser ao apostar na inocência e na "alegria" (Flusser 1998a: 170) dos brasileiros, ao acreditar na existência do brasileiro “autêntico" (1998a) só poderia levá-lo à desilusão com este projeto para o Brasil, que já fora considerado "país do Futuro", no dizer de outro judeu emigrado fugitivo do nazismo. De fato, olhando esta coincidência de leitura de Stefan Zweig e Flusser, parece que este tipo de interpretação do Brasil deve-se mais à vivência de perseguido na Europa e a uma necessidade de "reencantar o mundo", do que propriamente, como Flusser acreditou, à visão mais aguda do imigrante com seu ponto de vista distanciado. O desapontamento com o seu “engajamento" pelo Brasil está descrito

\footnotetext{
${ }^{7}$ Apesar de, em alguns momentos de lucidez, ser crítico com relação a esta categoria. Cf. F 104, 166.

${ }^{8}$ Flusser 1998a: 148s.; cf. também Flusser 1992: 257 e 1996: 14.
} 
em Bodenlos (Flusser 1998a: 255ss.). Ai ele aponta como ele percebeu no golpe de 1964 uma escolha do Brasil no sentido de adentrar a história e abandonar seu potencial de modelo revolucionário pós-histórico. Ele sentiu também aos poucos que estava na hora de novamente se mudar.

É interessante reencontrar muitas idéias de Flusser com relação ao Brasil e sua aposta neste país como um modelo, sem contar a idéia da cordialidade natural do brasileiro, no poeta e político senegalense Leopold Sedar Senghor (1906-2001). De sua experiência de prisão nas mãos dos nazistas nos anos 1930 e 1940 Senghor deduziu uma nova teoria da negritude, desta vez não mais fechada e localista, como ele antes defendera, mas sim aberta, voltada para o diálogo com outras culturas. Senghor desenvolveu um conceito de "civilisation de l'universel" que deve muito ao que ele conhecia do Caribe e ao que viu no Brasil e que ele classificou como sendo este convívio pacífico de três matrizes: a latina, a indígena e a africana. O interessante nesta proposta é que ela pode ser dialeticamente desdobrada em uma crítica da própria tese das matrizes "puras". Ou seja, o pensamento pós-colonial de Senghor pode servir hoje para pensarmos novos modelos dialógicos de identidade. $\mathrm{O}$ mesmo pode ser feito com a teoria flusseriana da circulação entre as línguas como meio de se alargar os horizontes e desconstruir a Heimat que mora dentro de cada um de nós. Com ela podemos não apenas criticar os próprios momentos em que Flusser recai no essencialismo. Muito mais importante é descobrir um local ao lado de Flusser no seu projeto de nomadismo lingüístico e cultural que nos permita, na nossa época de fundamentalismos, quebrar nossos cascos nacionalistas e avessos ao diálogo. Com Flusser aprendemos que cada um de nós pode construir sua própria ponte para fora da Heimat e em direção ao "outro". Neste sentido a sua obra realizou seu anelo de se transformar em um modelo e de extrair vida do fundo da catástrofe.

\section{Obras citadas:}

CYTRYNOWICZ, R. "Cotidiano, imigração e preconceito: a comunidade judaica nos anos 1930 e 1940”. In: GRINBERG, K. (ed.): Os judeus no Brasil, Rio de Janeiro: Civilização Brasileira, 2005. P. 287-314.

DERRIDA, J. O monolinguismo do outro ou a Prótese da origem. Trad. F. Bernardo, Porto: Campo das Letras. 2001. 
FLUSSER, V. "Sobre a Ponte de Avignon" em O Estado de S.Paulo, (675): 3, 20.06.70.

. Bodenlos. Eine philosophische Autobiographie. Düsseldorf; Bensheim: Bollmann. 1992.

. Jude Sein. Essays, Briefe, Fiktionen. In.: Stefan Bollmann e Edith Flusser (org.). Düsseldorf; Bensheim: Bollmann. 1995.

Zwiegespräche. Interwiews 1967-1991. In.: SANDER, K. (org.), Göttingen: European Photography. 1996.

. Fenomenologia do Brasileiro. Em busca de um Novo Homem. Rio de janeiro: Eduerj. 1998a.

. Ficções Filosóficas. São Paulo: EDUSP. 1998b.

Da Religiosidade. A Literatura e o senso de realidade. São Paulo: Escrituras. 2002.

. Língua e Realidade. São Paulo: AnnaBlume, 2a . Ed. 2004a.

. "Probleme mit der Übersetzung". In.: GULDIN, R. (ed.): Das Spiel mit der Übersetzung. Figuren der Mehrsprachigkeit im Werk Vilém Flussers. Tübingen; Basel: Francke Verlag, 2004b, p.15-46.

GASPARINI, P. "Desertar da Memória: o exílio em Transatlántico e em Diario de Witold Gombrowicz". Remate de Males, revista do departamento de Teoria Literária, UNICAMP, Campinas, 26.1, 2006.

HEGEL, G.W.F. Werke. Frankfurt a.M.: Suhrkamp. 1993.

HOLANDA, S. B. DE. Raízes do Brasil. São Paulo: Companhia das Letras. 1995.

LESSER, J. "Judeus salvam judeus: os estereótipos e a questão dos refugiados no Brasil, 1935-1945", em GRINBERG, K. (ed.). Os judeus no Brasil. Rio de Janeiro: Civilização Brasileira, 2005. P. 315-334.

SEMPRUN, J. Mal et modernité. Paris: Éditions Climats. 1995. 